\title{
The effect of Dimethyl Sulfoxide (DMSO) on the development of 10-days chicken embryo based on body length and head diameter
}

Herlina Pratiwi*1), Analis Wisnu Wardana ${ }^{2)}$, Dyah Ayu Okatvianie A.P ${ }^{3)}$, Albiruni Haryo ${ }^{3)}$, Nayo Diah Fauziah" ${ }^{4}$, Rizky Pamwidya Abqariyyan ${ }^{4}$, Rifkytri Aditia ${ }^{4)}$, Syadza Afra ${ }^{4)}$

1) Embryology Laboratory, Faculty of Veterinary Medicine, Brawijaya University, Jl.

Veteran, Ketawanggede, Kec. Lowokwaru, Kota Malang, Jawa Timur, Indonesia 65145

2) Anatomy Laboratory, Faculty of Veterinary Medicine, Brawijaya University, Jl. Veteran, Ketawanggede, Kec. Lowokwaru, Kota Malang, Jawa Timur, Indonesia 65145

3) Patological Anatomy Laboratory, Faculty of Veterinary Medicine, Brawijaya University,

J1. Veteran, Ketawanggede, Kec. Lowokwaru, Kota Malang, Jawa Timur, Indonesia 65145

${ }^{4)}$ Student of Faculty of Veterinary Medicine, Brawijaya University, Jl. Veteran,

Ketawanggede, Kec. Lowokwaru, Kota Malang, Jawa Timur, Indonesia 65145

Submitted:06 November 2019, Accepted: 11 September 2020

\begin{abstract}
This research aims to understand the effect of dimethyl sulfoxide (DMSO) on the body length and head diameter of chicken embryos. The samples used in this research were 3 days chicken egg embryos weighed at $55 \mathrm{~g}$. The samples were divided into two groups, the control group (without DMSO) and treatment group (injected with $0.25 \mathrm{~mL}$ of $2 \%$ DMSO). Each group was incubated at $38^{\circ} \mathrm{C}$ for 10 days, and the observed variables were embryos body length and head diameter through macroscopic observation. The results showed that $2 \%$ DMSO did not affect the embryos body length, but increase its head diameter. The research concludes that DMSO can be used as chemical solvent with consideration of its effect on the increased embryos head diameter.
\end{abstract}

Keywords: DMSO; Chicken eggs; Embryos body length; Embryos head diameter

*Corresponding Author: herlinapratiwi.drh@ub.ac.id 


\section{INTRODUCTION}

Dimethyl sulfoxide (DMSO) is a chemical compound that commonly used to solve non-polar compounds. However, the use of the simple compound has caused controversies among researchers or popular publication. Some non-polar therapeutic and toxic agents could be dissolved in DMSO as the compound has high affinity to water. Aside from easily dissolved when exposed with air, other physiological and pharmaceutical properties of the compound is not comprehensively understood. On the other hand, the compound had high penetration as well as increase other compounds penetration on biological membranes, free radicals, coagulative property, anticholinesterase activity and could induce the release of histamine by the mast cell. Moreover, the systemic toxicity of DMSO is known to be low even though the combination of DMSO with other toxic compounds could increase its toxicity. The current usage of DMSO is still limited on certain animals (Brayton, 1986), with the common usage of the compound is for cryoprotectant for the animals embryo (Suzuki et al., 1995). The DMSO also plays several roles on cell function and development by affecting cell cycle and apoptosis (Santos et al., 2003). The embryonic growth is highly correlated with the cell function and development; thus, a more in-depth research should be done to understand the DMSO toxicity towards embryo development.

The observation of compounds toxicity has been widely done on chicken embryo, with the chicken egg as the learning model to observe embryonic development. The animal that is used as research model has an essential role for fundamental and medical research. The advance on medical innovation, such as regenerative and cancer drugs depends on the in vivo model to validate the finding, and open a novel approach for therapeutic medication. However, the research on conventional rodent or big animals often faced ethical, practical and technical difficulties. The usage of chicken embryo available on its egg is then offer a more accessible and economical model for in vivo research for genetic development and expression analysis. The chicken egg embryo also showed its potential to be used as cell transplantation for stem cell and cancer research (Rashidi \& Sottile, 2009). In this research, chicken egg embryo is used as research model to understand the effect of DMSO to the embryonic development by measuring the body length and head diameter of the embryo.

\section{MATERIALS AND METHODS}

This research used 10 native chicken egg embryos at 0 days old obtained from Mojokerto. The chicken eggs were weighed at 55 grams, and then incubated for three days. The occurrence of embryo in the chicken eggs was observed through candling method by using egg candler. The chicken egg that had developed embryo showed embryonic disck (black spot) on one side of the egg yolk. The chicken eggs with embryo were then divided into negative group and the other five eggs into positive group (inoculated with $2 \%$ DMSO). For the positive group, the chicken eggs were incubated at $39^{\circ} \mathrm{C}$ for three days and then inoculated with $0.25 \mathrm{~mL}$ of $2 \%$ DMSO. The $2 \%$ DMSO inoculation was done on the egg sac observed with egg candler on dark room and marked with pencil (Murtini et al., 2014). The next step was piercing the eggs by. Using spuit needle on the marked area and then injected with $2 \%$ DMSO as according to the research treatment. The hole was then covered with paper tape and labeled.

The body length and head diameter of the embryo was done after 10 days inoculation which indicates the time of complete organogenesis. The embryos were then stored at $4^{\circ} \mathrm{C}$ for 24 hours to stop the embryo growth (Putra et al., 2012). The embryo is then collected from the shell and cleaned from excess embryonic membrane. 
The body length of the embryo was measured by sticking a thread on dorsal embryonic body from os frontal to os cauda (Figure $1 \mathrm{~A})$. The head diameter of the embryo was measured by using calipers on median os fontral to median os occipital (Figure $1 \mathrm{~B}$ ). The embryonic development then compared and analyzed descriptively.
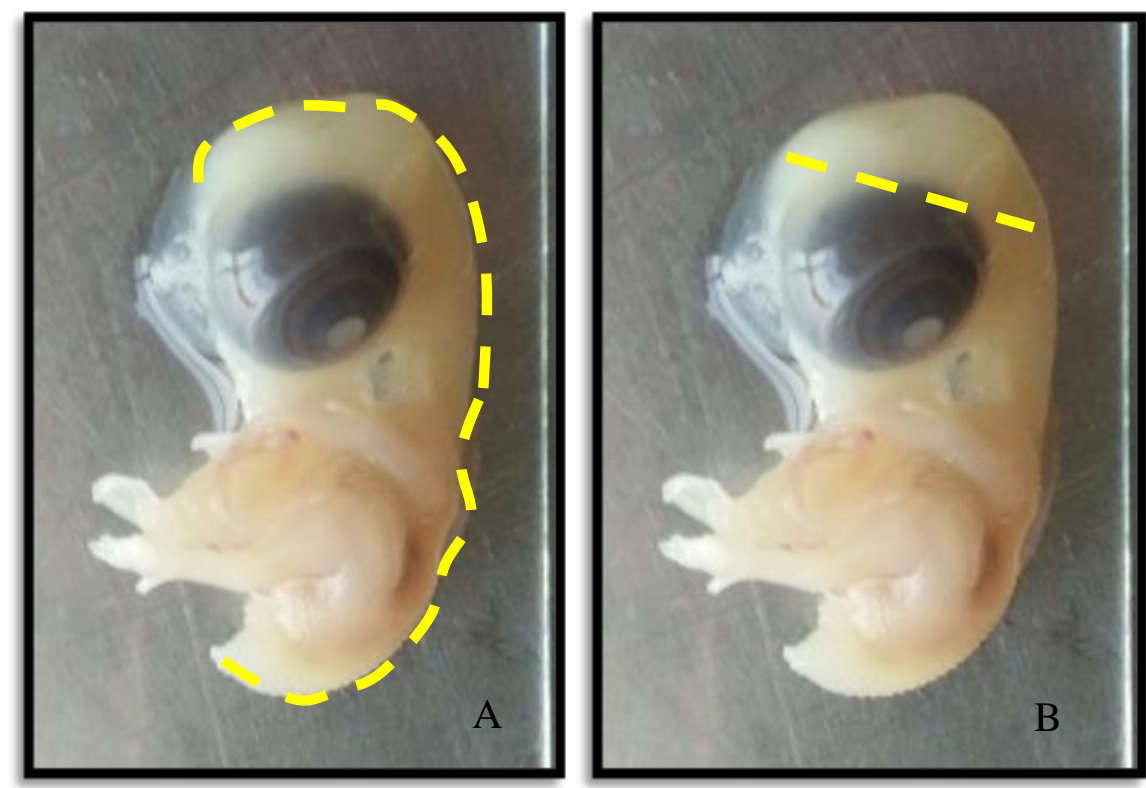

Figure 1. Measurement of chicken embryo body length (A) and head diameter (B).

\section{RESULTS AND DISCUSSION}

The body length and head diameter of chicken embryo measurement was done after stored at $5^{\circ} \mathrm{C}$ for 24 hours. The results showed small body length increase on the positive group (2\% DMSO) compared to the negative group (Table 1).

The body length of 10 days old chicken embryo (Table 1) on negative group was $35.17 \mathrm{~mm} \pm 1.48$, while on the positive group was $36.48 \mathrm{~mm} \pm 4.03$, with $1.29 \mathrm{~mm}$ or $3.72 \%$ difference. Dimethyl sulfoxide (DMSO) is an organosulfur compound with chemical formula $\left(\mathrm{CH}_{3}\right) 2 \mathrm{SO}$ and had molecular weight at $78.13 \mathrm{~g} / \mathrm{mol}$, which cause the compound to be penetrate faster into cell. The correct dosage DMSO would help dissolve both polar and non-polar compounds into various organic compounds and would not affect the embryonic growth (Gazali \& Tambin, 2001). The study of cryoprotectant toxicity showed that DMSO and methanol did not significantly affect embryonic growth (Kopeika et al., 2003).

The embryo head development of 10 days old embryo, both in negative and positive group, was observed by macroscopic anatomy observation. The embryo head measurement was done by using calipers from median os frontal to median os occipital, and the results are presented in Table 2.

Table 1. Body length of the chicken embryo at 10 days

\begin{tabular}{lc}
\hline Group & Mean \pm SD $(\mathrm{mm})$ \\
\hline Negative & $35.17 \pm 1.48$ \\
Positive (2\% DMSO) & $36.48 \pm 4.03$ \\
\hline
\end{tabular}

Table 2. Head diameter of tha chiken embryo at 10 days

\begin{tabular}{lc}
\hline Group & Mean \pm SD $(\mathrm{mm})$ \\
\hline Negative & $9.70 \pm 0.44$ \\
Positive (2\% DMSO) & $11.69 \pm 0.59$ \\
\hline
\end{tabular}


The results showed an increased chicken embryo head diameter after $2 \%$ DMSO inoculation. The positive group had $1.99 \mathrm{~mm}$ larger head diameter compared to the negative group. The chicken embryo development was occurred on a high temperature $\left(39^{\circ} \mathrm{C}\right)$. Dimethyl sulfoxide (DMSO) is known to be able to protect frozen enzyme, while on the hand could maintain protein stability during high temperature (Anchordoguy et al., 1992). The embryo head diameter has a close correlation to the brain development, which is the central nerve system protected with cranium. Moreover, the usage of DMSO is commonly on a very low concentration to develop new antioxidant as neuro protector. The neuroprotective effect is due to the DMSO property that binds excessive free radicals and prevent cell disruption from $\mathrm{Na}^{+}$and $\mathrm{Ca}^{2+}$ penetration to the brain cells and inhibits the NMDA-AMPA activity (Suarez et al., 2011). Santos et al., (2003) described that DMSO acts as celldifferentiating agent and widely used as medication for cerebral edema. These showed that DMSO at low concentration would act as protective agent against temperature and as neuroprotective agent, even though the mechanism is still unclear.

\section{CONCLUSION}

The inoculation of $2 \%$ DMSO as much as $2 \mathrm{~mL}$ on each egg increased the body length and head diameter of 10 days old chicken embryo, even though the increase was significantly low. The mechanism of the embryo body length and head diameter is still unclear, and the results suggest further research to understand the mechanism.

\section{ACKNOWLEDGEMENTS}

Authors would like to thank the laboratory of Veterinary Microbiology and Immunology, Laboratory of Histology and Laboratory Embryologi, Faculty of Veterinary Medicine, University of Brawijaya for the help in this research. We would also like to thank Faculty of
Veterinary Medicine, University of Brawijaya for the research fund through DPPSPP scheme.

\section{REFERENCES}

Anchordoguy, T. J., Carpenter, J. F., Crowe, J. H., \& Crowe, L. M. (1992). Temperature-dependent perturbation of phospholipid bilayers by dimethylsulfoxide. Biochimica et Biophysica Acta (BBA) Biomembranes, 1104(1), 117-122. https://doi.org/10.1016/0005-2736(92 )90139-D

Brayton, C. F. (1986). Dimethyl sulfoxide (DMSO): a review. In The Cornell veterinarian (Vol. 76, Issue 1).

Gazali, M., \& Tambin. (2001). Kriopreservasi sel spermatozoa. Jurnal Hayati, 9(1), 27-32.

Hamjaya, P. H., Haryadi, W. M., Tri, U., \& Kurniasih. (2012). Studi lesi makroskopis dan mikroskopis embrio ayam yang diinfeksi virus newcastle disease isolat lapang yang virulen. Jurnal Sain Veteriner, 30(1), 57-67.

Kopeika, J., Kopeika, E., Zhang, T., \& Rawson, D. M. (2003). Studies on the toxicity of dimethyl sulfoxide, ethylene glycol, methanol and glycerol to loach (Misgurnus fossilis) sperm and the effect on subsequent embryo development. Cryo-Letters, 24(6), 365-374.

Murtini, S., Murwani, R., Satrija, F., \& Malole, M. (2014). Penetapan rute dan dosis inokulasi pada telur ayam berembrio sebagai media uji khasiat ekstrak benalu teh (Scurrula oortiana). JITV, 11(2), 137-143.

Rashidi, H., \& Sottile, V. (2009). The chick embryo: hatching a model for contemporary biomedical research. BioEssays, 31(4), 459-465. https:// doi.org/10.1002/bies.200800168

Sanmartín-Suárez, C., Soto-Otero, R., Sánchez-Sellero, I., \& MéndezÁlvarez, E. (2011). Antioxidant properties of dimethyl sulfoxide and its viability as a solvent in the 
evaluation of neuroprotective antioxidants. Journal of Pharmacological and Toxicological Methods, 63(2), 209-215. https:// doi.org/10.1016/j.vascn.2010.10.004

Santos, N. C., Figueira-Coelho, J., MartinsSilva, J., \& Saldanha, C. (2003). Multidisciplinary utilization of dimethyl sulfoxide: pharmacological, cellular, and molecular aspects.
Biochemical Pharmacology, 65(7), 1035-1041. https://doi.org/10.1016/S 0006-2952(03)00002-9

Suzuki, T., Komada, H., Takai, R., Arii, K., \& Kozima, T. T. (1995). Relation between toxicity of cryoprotectant dmso and its concentration in several fish embryos. Fisheries Science, 61(2), 193-197. https://doi.org/10.23 31/fishsci.61.193 